\title{
Iridoids from Canthium subcordatum iso-butanol fraction with potent biological activities
}

\author{
Christelle Joubouhi ${ }^{1}$, Jean-de-Dieu Tamokou ${ }^{2 *}$, David Ngnokam ${ }^{1 *}$, Laurence Voutquenne-Nazabadioko ${ }^{3}$ \\ and Jules-Roger Kuiate ${ }^{2}$
}

\begin{abstract}
Background: The continuous emergence of multi-drug-resistant bacteria drastically reduces the efficacy of antibiotic armory and, consequently, increases the frequency of therapeutic failure. The discovery of new antibacterial drugs is an urgent need. The present study reports the antibacterial and antioxidant activities of the methanol extract, fractions and iridoids from Canthium subcordatum, a plant traditionally used as antidiabetic, anti-inflammatory, and antimicrobial.

Methods: Broth microdilution assay was used to determine minimum inhibitory concentrations (MICS) and minimum bactericidal concentrations (MBCs) of extracts and iridoids against Staphylococcus aureus, Vibrio cholerae and Shigella flexneri. Antioxidant activity was evaluated using 1,1-diphenyl-2-picrylhydrazyl (DPPH) and gallic acid equivalent antioxidant capacity (GAEAC) assays. The samples were also tested for their cytotoxicity against human red blood cells (RBC).

Results: The methanol extract, hexane, ethyl acetate and iso-butanol fractions from C. subcordatum fruits displayed different degrees of antioxidant $\left(E_{50}=62.83-70.17 \mu \mathrm{g} / \mathrm{ml}\right.$; GAEAC $=45.63-58.23 \mu \mathrm{g} / \mathrm{ml}$ ) and antibacterial $(\mathrm{MIC}=128-512 \mathrm{\mu g} / \mathrm{ml})$ activities. Canthiumoside 1(1) and linearin (7) were the most active antioxidant $\left(E_{50}=1.12-2.03 \mu \mathrm{g} / \mathrm{ml} ; \mathrm{GAEAC}=79.82-92.35 \mu \mathrm{g} / \mathrm{ml}\right)$ and antibacterial $(\mathrm{MIC}=8-64 \mu \mathrm{g} / \mathrm{ml})$ compounds while the most sensitive bacterium was Staphylococcus aureus. The tested samples were non-toxic to normal cells.
\end{abstract}

Conclusion: Our results demonstrated that compounds 1 and 7 were potent antibacterial agents and DPPH/ABTS. ${ }^{+}$ radical scavengers, so they warrant further investigation.

Keywords: Canthium subcordatum, Rubiaceae, Fruit extracts, Phytochemical analysis, Iridoids, Antimicrobial, Antioxidant

\section{Background}

The uses of plants in the indigenous cultures of developing countries are numerous and diverse. For many people, the high cost of imported conventional drugs and/or inaccessibility to western health care facilities has led to overreliance on traditional medicine since it is affordable and available to rural people. On the other hand, even when western

\footnotetext{
* Correspondence:

jtamokou@yahoo.fr; jean.tamokou@univ-dschang.org; dngnokam@yahoo.fr; ngnokam@univ-dschang.org

${ }^{2}$ Department of Biochemistry, Laboratory of Microbiology and Antimicrobia Substances, Faculty of Science, University of Dschang, P.O. Box 67 Dschang, Cameroon

${ }^{1}$ Department of Chemistry, Laboratory of Environmental and Applied Chemistry, Faculty of Science, University of Dschang, P.O. Box 67 Dschang, Cameroon

Full list of author information is available at the end of the article
}

health facilities are available, traditional medicine is viewed as an efficient and an acceptable system from a cultural perspective $[1,2]$. Oxidative stress and diarrheal diseases are among some of the indications treated using traditional remedies in Cameroon. Diarrheal disease is a leading cause of child mortality and morbidity in the world due to various factors such as the HIV/AIDS pandemic, poor hygiene, overcrowding and resistance to conventional antibacterials while oxidative stress can lead to many illnesses including cardiovascular diseases, diabetes, inflammation, degenerative diseases, cancer, anemia, and ischemia [3]. Among the diarrheal diseases, cholera is a serious epidemic disease caused by the gram-negative bacterium Vibrio cholerae [4]. Vibrio cholerae, serotypes $\mathrm{O} 1$ and $\mathrm{O} 139$ has ability to produce an enterotoxin, cholera toxin that is a major 
determinant of virulence for cholera. There is a consensus among the scientific community that plant derived products have been playing a dominant role in the discovery of leads for the development of drugs for the treatment of human diseases [3]. Canthium subcordatum (formely Psydrax subcordata) belonging to Rubiaceae family is a tree which grows in central and western Africa and reaches a height of more than $10 \mathrm{~m}$ [5]. Its roots, leaves and stem bark are used for medicinal purposes [6]. Alcoholic extracts of the stem bark have potential antidiabetic properties [6] and roots were used to treat malaria fever, inflammation and cardiovascular disease [7]. Petroleum ether and dichloromethane extracts of $C$. subcordatum have shown anti-inflammatory activity in COX-1 and COX-2 assays [8]. Previous phytochemical works on this plant species and other Canthium species revealed the presence of iridoids [8-10], iridoid peptidic alkaloids [11, 12], flavonoids [10], terpenoids and miscellaneous [12, 13]. However, it is not yet known which of the phytoconstituents is responsible of the antimicrobial effect of this plant, when it is used to cure infectious diseases and oxidative stress conditions. Therefore, the present study reports the antibacterial and antioxidant activities of extracts and iridoids from C. subcordatum fruits.

\section{Methods}

\section{Plant material}

The fruits of Canthium subcordatum DC (syn. Psydrax subcordata DC Bridson) were collected in Foto village (Menoua Division, Western region of Cameroon), in April 2012. Authentication was performed by Victor Nana, a Botanist of the Cameroon National Herbarium, Yaoundé, where a voucher specimen (N 19579/SRF/CAM) has been deposited.

\section{Experimental}

The melting point, optical rotation, IR, ${ }^{1} \mathrm{H}$ NMR, ${ }^{13} \mathrm{C}$ NMR, COSY, NOESY, HSQC, HMBC and HR-TOFESIMS experiments were performed as previously described [10].

\section{Extraction and isolation}

The iso-butanol, ethyl acetate and hexane fractions as well as the isolated compounds were obtained as previously described [10]. Briefly, the dried fruits of $C$. subcordatum $(3.50 \mathrm{~kg})$ were extracted with $\mathrm{MeOH}$, and the resulting crude extract was suspended in water and successively extracted with $n$-hexane, ethyl acetate and iso-butanol to yield hexane, ethyl acetate and iso-butanol fractions. The hexane and iso-butanol-solute fractions were further fractionated and purified over silica gel column chromatography to yield compounds 11-12 and 1-10 respectively [10]. None compound has been isolated after the fractionation of the ethyl acetate fraction.
Structure elucidation by spectroscopy techniques showed that they are canthiumosides $1-4$ and $5 \mathbf{a}(\mathbf{1}-\mathbf{4}, 5 \mathbf{5})$, shanzhigenin methyl ester (6) and 1-epishanzhigenin methyl ester (6'), linearin (7) and 1-epilinearin (7'), mussaenoside (8), shanzhiside methyl ester (9), 3,4,7trihydroxyflavone (10), betulinic acid (11), and oleanolic acid (12) (Fig. 1).

\section{Antibacterial assay \\ Microorganisms}

A total of six bacterial strains were tested for their susceptibility to compounds and these strains were taken from our laboratory collection (kindly provided by Dr. T. Ramamurthy, NICED, Kolkata). Among the clinical strains of Vibrio cholerae used in this study, strains NB2 and SG24(1) belonged to O1 and O139 serotypes, respectively. These strains were able to produce cholera toxin and hemolysin. The other strains used in this study were $V$. cholerae non-O1, non-O139 (strains CO6 and PC2); and Shigella flexneri SDINT. The $V$. cholerae non-O1 and non-O139 strains, were positive for hemolysin production but negative for cholera toxin production. The strains of $V$. cholerae and $S$. flexneri included in the present study were MDR clinical isolates and these were resistant to commonly used drugs such as ampicillin, streptomycin, tetracycline, nalidixic acid, furazolidone, co-trimoxazole, etc. A reference strain, Staphylococcus aureus ATCC 25923, was used for quality control. The bacterial strains were maintained on agar slant at $4{ }^{\circ} \mathrm{C}$ and subcultured on a fresh appropriate agar plates $24 \mathrm{~h}$ prior to any antibacterial test. The Mueller Hinton Agar (MHA) was used for the activation of bacteria. The Mueller Hinton Broth (MHB) and nutrient agar (Hi-Media) were used for the MIC and MBC determinations respectively.

Determination of minimum inhibitory concentration (MIC) and minimum bactericidal concentration (MBC)

MIC values were determined by a broth micro-dilution method as described earlier [14] with slight modifications. Each test sample was dissolved in dimethylsulfoxide (DMSO) and the solution was then added to Mueller Hinton Broth (MHB) to give a final concentration of $1024 \mu \mathrm{g} / \mathrm{ml}$. This was serially diluted twofold to obtain a concentration range of $0.50-1024 \mu \mathrm{g} / \mathrm{ml}$. Then, $100 \mu \mathrm{l}$ of each concentration was added in each well (96-well microplate) containing $95 \mu \mathrm{l}$ of $\mathrm{MHB}$ and $5 \mu \mathrm{l}$ of inoculums (at $1.5 \times 10^{6} \mathrm{CFU} / \mathrm{ml}$ ) for final concentrations varying from $0.25-512 \mu \mathrm{g} / \mathrm{ml}$. Dilutions of Ciprofloxacin and Ampicillin (256 - $0.125 \mu \mathrm{g} / \mathrm{ml})$ served as positive controls, while broth with $5 \mu \mathrm{L}$ of DMSO was used as negative control. The plates were covered with sterile lids, then the contents of each well 


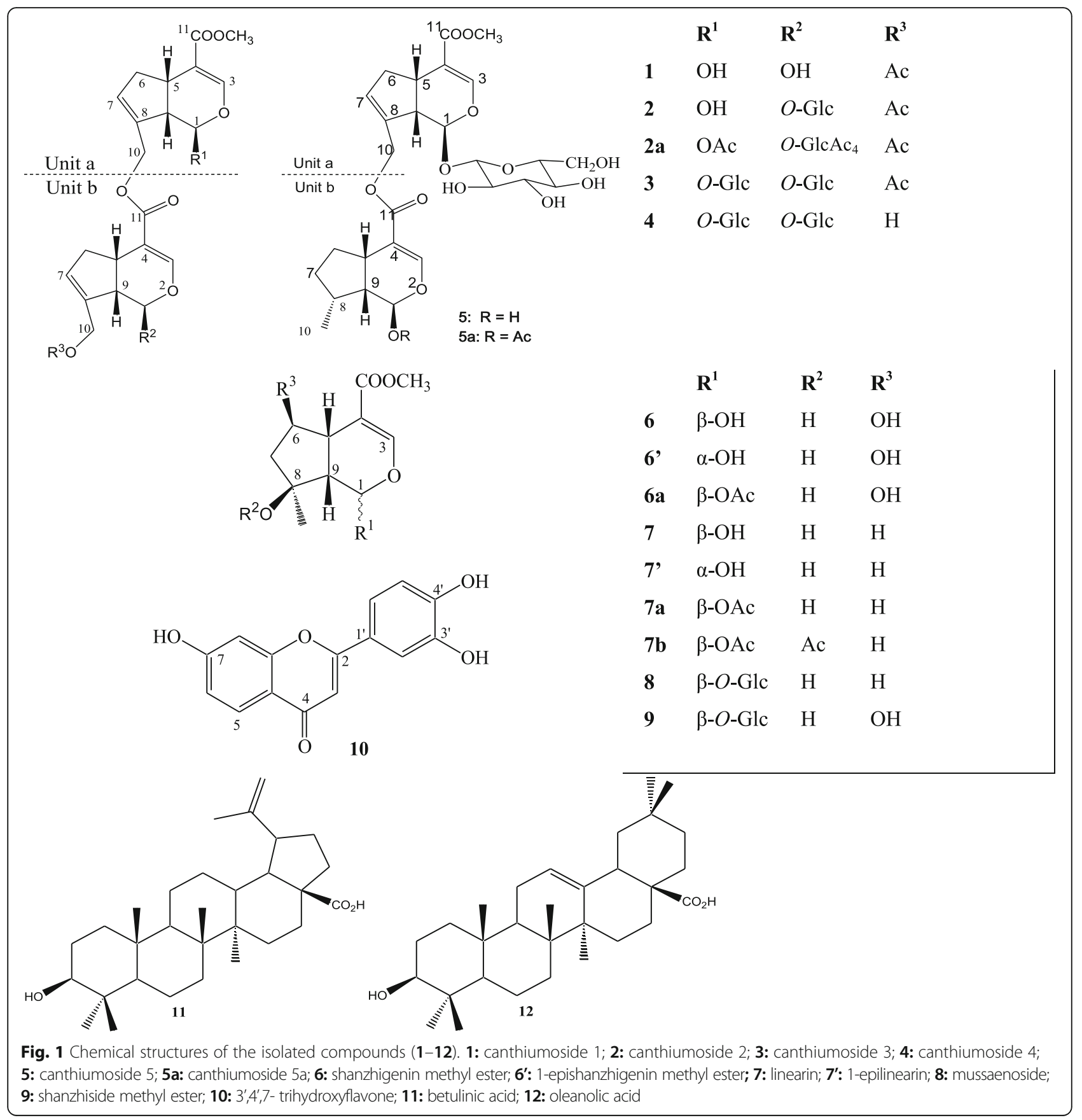

were mixed using a shaker and incubated at $35{ }^{\circ} \mathrm{C}$ for $24 \mathrm{~h}$. The MIC values of samples were determined by adding $50 \mu \mathrm{l}$ of a $0.20 \mathrm{mg} / \mathrm{ml} p$-iodonitrotetrazolium violet solution followed by incubation at $35{ }^{\circ} \mathrm{C}$ for $30 \mathrm{~min}$. MIC values were defined as the lowest sample concentrations that prevented this change in color indicating an inhibition of visible growth. Viable microorganisms reduced the yellow dye to a pink color. For the determination of minimum bactericidal concentration $(\mathrm{MBC})$ values, a portion of liquid $(5 \mu \mathrm{l})$ from each well that showed no growth of microorganism was plated on Mueller Hinton Agar and incubated at $35{ }^{\circ} \mathrm{C}$ for $24 \mathrm{~h}$. The lowest concentrations that yielded no growth after this subculturing were taken as the MBC values [15]. All the analyses were carried out in triplicate.

\section{Antioxidant assay}

DPPH free radical scavenging assay

The free radical scavenging activity of extracts as well as most of their isolated compounds was performed according 
to Brand-Williams et al. [16] with slight modifications. Briefly, different concentrations (10 to $2000 \mu \mathrm{g} / \mathrm{ml}$ ) of extracts/compounds and vitamin C (positive control) were thoroughly mixed with $3 \mathrm{ml}$ of methanolic DPPH solution $(20 \mathrm{mg} / \mathrm{l})$ in test-tubes and the resulting solution was kept standing for $30 \mathrm{~min}$ at room temperature before the optical density (OD) was measured at $517 \mathrm{~nm}$. The percentage radical scavenging activity was calculated from the following formula: \% scavenging $[\mathrm{DPPH}]=\left[\left(\mathrm{A}_{0}-\mathrm{A}_{1}\right) / \mathrm{A}_{0}\right] \times 100$ [16]. Where $A_{0}$ was the absorbance of the negative control (methanolic DPPH solution) and $\mathrm{A}_{1}$ was the absorbance in the presence of the samples. $\mathrm{IC}_{50}$ value was determined from the graph obtained using standard vitamin $C$ by using the " $y=m x+c$ " formula from the slope of the graph. All the analyses were carried out in triplicate.

\section{Gallic acid equivalent antioxidant capacity (GAEAC) assay}

The GAEAC test was done as previously described [17] with slight modifications. In a quartz cuvette, to $950 \mu \mathrm{l}$ acetate buffer $(\mathrm{pH}=5.0,100 \mathrm{mM})$, the following were added: $20 \mu \mathrm{l}$ laccase (1 $\mathrm{mM}$ stock solution), $20 \mu \mathrm{l}$ test sample, $10 \mu \mathrm{l}$ ABTS (2,2'-azinobis(3-ethylbenzothiazoline-6-sulfonic acid) (74 mM stock solution). The laccase were purified from Sclerotinia sclerotiorum according to the protocol described [18]. The sample concentrations in the assay mixture were 800, 400, 200, 100, $10 \mu \mathrm{g} / \mathrm{ml}$ for the extracts and 200, 100, 50, 25, $125.5 \mu \mathrm{g} / \mathrm{ml}$ for the isolated compounds. The content of the generated $\mathrm{ABTS}^{\bullet+}$ radical was measured at $420 \mathrm{~nm}$ after $240 \mathrm{~s}$ reaction time and was converted to gallic acid equivalents by the use of a calibration curve (Pearson's correlation coefficient: $r=0.996$ ) constructed with $0,4,10,14,28,56,84 \mu \mathrm{M}$ gallic acid standards rather than Trolox. Experiments were done in triplicate.

\section{Hemolytic assay}

Hemolysis test was performed to determine cellular toxicity of the compounds as previously described [19]. Whole blood $(10 \mathrm{ml})$ from a healthy man was collected into a conical tube containing heparin as an anticoagulant (blood group $\mathrm{O}$ was used). Extracts (at concentrations ranging from 32 to $2048 \mu \mathrm{g} / \mathrm{ml}$ ) and pure compounds (16 to $256 \mu \mathrm{g} / \mathrm{ml})$, were incubated with an equal volume of $1 \%$ human red blood cells in phosphate buffered saline (10 mM PBS, pH 7.4) at $37{ }^{\circ} \mathrm{C}$ for 1 h. $1 \%$ human red blood cells in buffer was used as a non-hemolytic control whereas buffer containing 1\% Triton X-100 and 1\% human red blood cells served as a $100 \%$ hemolytic control. Cell lysis was monitored by measuring the release of hemoglobin at
$540 \mathrm{~nm}$. The assay was repeated thrice. Percent hemolysis was calculated as follows:

$$
\left[\left(\begin{array}{l}
\text { A595 of sample treated with compound } \\
- \text { A595 of sample treated with buffer }
\end{array}\right)\right] \times 100
$$$$
\left[\left(\begin{array}{c}
\text { A595 of sample treated with Triton X-100 } \\
\text {-A595 of sample treated with buffer }
\end{array}\right)\right]
$$

\section{Statistical analysis}

Data were analyzed by one-way analysis of variance followed by Waller-Duncan Post Hoc test. The experimental results were expressed as the mean \pm Standard Deviation (SD). Differences between groups were considered significant when $p<0.05$. All analyses were performed using the Statistical Package for Social Sciences (SPSS, version 12.0) software.

\section{Results and discussion}

Antibacterial activity

In the present work, the extracts as well as 12 compounds isolated from the fruits of C. subcordatum were tested for their antibacterial activities against Vibrio cholerae, Shigella flexneri and Staphylococcus aureus (Table 1). The $\mathrm{MIC}$ results indicated that the $\mathrm{MeOH}$ extract, $n-\mathrm{BuOH}$ and EtOAc fractions as well as compounds 1, 2, 5a and 6-9 inhibited the growth of all tested bacterial species. Hexane fraction and compound $\mathbf{3}$ showed selective activities, their inhibitory effects being noted on 5 of the 6 (83.33\%) tested organisms. The lowest MIC values for the extracts $(128 \mu \mathrm{g} / \mathrm{ml})$ and compounds $(8 \mu \mathrm{g} / \mathrm{ml})$ were recorded on $S$. aureus. The most active extract was the EtOAc extract $(\mathrm{MIC}=128-512 \mu \mathrm{g} / \mathrm{ml})$ while compounds $1(\mathrm{MIC}=32-64 \mu \mathrm{g} / \mathrm{ml})$ and $7(\mathrm{MIC}=8-64 \mu \mathrm{g} / \mathrm{ml})$ were the most active compounds. Cut-off points for antimicrobial activities were defined as follows: (i) For crude extracts: significant activity $(\mathrm{MIC}<100 \mu \mathrm{g} / \mathrm{ml})$, moderate activity $(100<\mathrm{MIC} \leq 625 \mu \mathrm{g} / \mathrm{ml})$ or weak activity (MIC $>625 \mu \mathrm{g} / \mathrm{ml}$ ); (ii) For pure compounds: significant activity (MIC $<10 \mu \mathrm{g} / \mathrm{mL})$, moderate activity $(10<\mathrm{MIC} \leq$ $100 \mu \mathrm{g} / \mathrm{ml}$ ), and low activity (MIC > $100 \mu \mathrm{g} / \mathrm{ml})$ [20, 21]. Hence, the activity recorded herein for the extracts $(128<\mathrm{MIC} \leq 512 \mu \mathrm{g} / \mathrm{ml})$ and compounds 1 and $7(10<$ $\mathrm{MIC} \leq 100 \mu \mathrm{g} / \mathrm{ml})$ is moderate whereas that of compounds 2, 3, 5a, 6, 8 and $9(\mathrm{MIC}>100 \mu \mathrm{g} / \mathrm{ml})$ is low. The lowest MIC value of $8 \mu \mathrm{g} / \mathrm{ml}$ was recorded with compound 7 on Staphylococcus aureus, highlighting some medicinal potential for this compound, as the activity on $S$. aureus was equal to that of ampicillin. $S$. aureus is a major cause of community and hospitalassociated infection with an estimated mortality of around $7-10 \%[15,22]$. Moreover, about $2 \%$ of patients 
Table 1 Antibacterial activity (MIC and MBC in $\mu \mathrm{g} / \mathrm{ml}$ ) of extracts, isolated compounds and reference antibacterial drugs

\begin{tabular}{|c|c|c|c|c|c|c|c|}
\hline Extracts/compounds & Inhibition parameters & $\begin{array}{l}\text { Vibrio cholerae } \\
\text { SG24 (1) }\end{array}$ & $\begin{array}{l}\text { Vibrio cholerae } \\
\text { CO6 }\end{array}$ & $\begin{array}{l}\text { Vibrio cholerae } \\
\text { NB2 }\end{array}$ & $\begin{array}{l}\text { Vibrio cholerae } \\
\text { PC2 }\end{array}$ & $\begin{array}{l}\text { Shigella flexneri } \\
\text { SDINT }\end{array}$ & $\begin{array}{l}\text { Staphylococcus aureus } \\
\text { ATCC } 25923\end{array}$ \\
\hline \multirow[t]{3}{*}{$\mathrm{MeOH}$ extract } & $\mathrm{MIC}$ & 512 & 256 & 512 & 512 & 256 & 128 \\
\hline & $\mathrm{MBC}$ & 512 & 256 & 512 & 512 & 256 & 256 \\
\hline & $\mathrm{MBC} / \mathrm{MIC}$ & 1 & 1 & 1 & 1 & 1 & 2 \\
\hline \multirow[t]{3}{*}{$n-\mathrm{BuOH}$ extract } & $\mathrm{MIC}$ & 512 & 512 & 512 & 512 & 256 & 128 \\
\hline & $\mathrm{MBC}$ & $>512$ & 512 & 512 & $>512$ & 512 & 128 \\
\hline & MBC/MIC & / & 1 & 1 & / & 2 & 1 \\
\hline \multirow[t]{3}{*}{ EtOAc extract } & $\mathrm{MIC}$ & 512 & 128 & 256 & 512 & 256 & 128 \\
\hline & MBC & 512 & 256 & 512 & 512 & 512 & 128 \\
\hline & $\mathrm{MBC} / \mathrm{MIC}$ & 1 & 2 & 2 & 1 & 2 & 1 \\
\hline \multirow[t]{3}{*}{ Hexane extract } & $\mathrm{MIC}$ & $>512$ & 512 & 512 & 512 & 256 & 256 \\
\hline & $\mathrm{MBC}$ & / & $>512$ & $>512$ & $>512$ & $>512$ & $>512$ \\
\hline & $\mathrm{MBC} / \mathrm{MIC}$ & / & / & / & / & / & / \\
\hline \multirow[t]{3}{*}{1} & $\mathrm{MIC}$ & 64 & 64 & 64 & 64 & 32 & 32 \\
\hline & $\mathrm{MBC}$ & 128 & 64 & 64 & 64 & 64 & 32 \\
\hline & MBC/MIC & 2 & 1 & 1 & 1 & 2 & 1 \\
\hline \multirow[t]{3}{*}{2} & MIC & 256 & 128 & 128 & 256 & 128 & 64 \\
\hline & $\mathrm{MBC}$ & $>256$ & 256 & 128 & 256 & 256 & 64 \\
\hline & MBC/MIC & / & 2 & 1 & 1 & 2 & 1 \\
\hline \multirow[t]{3}{*}{3} & $\mathrm{MIC}$ & $>256$ & 128 & 256 & 256 & 256 & 256 \\
\hline & $\mathrm{MBC}$ & / & 256 & 256 & $>256$ & $>256$ & $>256$ \\
\hline & MBC/MIC & / & 2 & 1 & / & / & / \\
\hline \multirow[t]{3}{*}{$5 a$} & $\mathrm{MIC}$ & 256 & 128 & 128 & 128 & 128 & 128 \\
\hline & $\mathrm{MBC}$ & $>256$ & 256 & 128 & 256 & 128 & 128 \\
\hline & $\mathrm{MBC} / \mathrm{MIC}$ & / & 2 & 1 & 2 & 1 & 1 \\
\hline \multirow[t]{3}{*}{6} & MIC & 128 & 256 & 256 & 128 & 32 & 32 \\
\hline & $\mathrm{MBC}$ & 256 & 256 & 256 & 256 & 64 & 64 \\
\hline & MBC/MIC & 2 & 1 & 1 & 2 & 2 & 2 \\
\hline \multirow[t]{3}{*}{7} & $\mathrm{MIC}$ & 32 & 64 & 32 & 32 & 16 & 8 \\
\hline & $\mathrm{MBC}$ & 64 & 128 & 32 & 32 & 16 & 8 \\
\hline & MBC/MIC & 2 & 2 & 1 & 1 & 1 & 1 \\
\hline \multirow[t]{3}{*}{8} & MIC & 256 & 256 & 128 & 128 & 128 & 64 \\
\hline & $\mathrm{MBC}$ & $>256$ & 256 & $>256$ & 256 & 256 & 128 \\
\hline & $\mathrm{MBC} / \mathrm{MIC}$ & / & 1 & / & 2 & 2 & 2 \\
\hline \multirow[t]{3}{*}{9} & MIC & 128 & 128 & 128 & 256 & 128 & 128 \\
\hline & $\mathrm{MBC}$ & 128 & $>256$ & 128 & 256 & 256 & 256 \\
\hline & $\mathrm{MBC} / \mathrm{MIC}$ & 1 & / & 1 & 1 & 2 & 2 \\
\hline \multirow[t]{3}{*}{ Ampicillin } & MIC & 16 & 16 & $>512$ & $>512$ & $>512$ & 8 \\
\hline & $\mathrm{MBC}$ & 16 & 16 & $>512$ & $>512$ & $>512$ & 8 \\
\hline & MBC/MIC & 1 & 1 & / & / & / & 1 \\
\hline \multirow[t]{3}{*}{ Ciprofloxacin } & MIC & 8 & 8 & 16 & 16 & 16 & 2 \\
\hline & $\mathrm{MBC}$ & 8 & 8 & 16 & 16 & 16 & 2 \\
\hline & $\mathrm{MBC} / \mathrm{MIC}$ & 1 & 1 & 1 & 1 & 1 & 1 \\
\hline
\end{tabular}

/ not determined, $M I C$ minimum inhibitory concentration, $M B C$ minimum bactericidal concentration 
in Cameroon are infected by Staphylococcus spp [14]. Each year, some 500,000 patients in American hospitals contract a staphylococcal infection [15, 22]. Such findings stress the importance of finding an antibiotic against which Staphylococcus aureus is sensitive. It can also be noted that the reference antibiotics were in most of the case more active than all studied samples, except on Vibrio cholerae NB2, Vibrio cholerae PC2 and Shigella flexneri where ampicillin was not active. However, these bacterial strains were found to be sensitive to most of the tested samples, suggesting that their administration may represent an alternative treatment against the $V$. cholerae, the causative agent of cholera and S. flexneri, the causative agent of shigellosis. Taking into account the medical importance of the tested bacteria, this result can be considered as promising in the perspective of new antibacterial drugs development. Although iridoids (sanshiside methyl ester, sanshiside-D, mussaein, verbascoside, plumieride, protoplumericin A, plumieride acid, plumericin and isoplumericin) have been reported to possess antiviral, antimicrobial, anticancer and antioxidant properties [23-28], this study report for the first time the antibacterial activity of iridoids on MDR clinical multi-drug resistant (MDR) pathogenic bacteria.
The results of Table 1 also showed detectable MBC values for most of the studied samples on the tested bacterial strains. When analysing carefully the MIC and $\mathrm{MBC}$ results for the extracts and compounds, it can be noted that $\mathrm{MBC} / \mathrm{MIC}$ ratios lower than 4 were obtained with these samples on most of the tested microbial species, suggesting that a bactericidal effect could be expected $[29,30]$.

\section{Antioxidant activity}

Plant based antioxidant compounds [31, 32] play a defensive role by preventing the generation of free radicals and hence are extremely beneficial to alleviate the diseases caused by oxidative stress such as cardiovascular diseases, diabetes, inflammation, degenerative diseases, cancer, anemia, and ischemia [33, 34]. In this study, free radical scavenging capacities were measured using DPPH radical and ABTS radical cation. The results are expressed as gallic acid equivalent antioxidant capacity of tested samples (Figs. 2 and 3) and as equivalent concentrations of test samples scavenging $50 \%$ of DPPH radical (Fig. 3). Compounds $1 \quad\left(E_{50}=2.03 \mu \mathrm{g} / \mathrm{ml}\right.$; $\mathrm{GAEAC}=79.82 \mu \mathrm{g} / \mathrm{ml})$ and $7 \quad\left(\mathrm{EC}_{50}=1.12 \mu \mathrm{g} / \mathrm{ml}\right.$; GAEAC $=92.35 \mu \mathrm{g} / \mathrm{ml}$ ) exerted the greatest activity

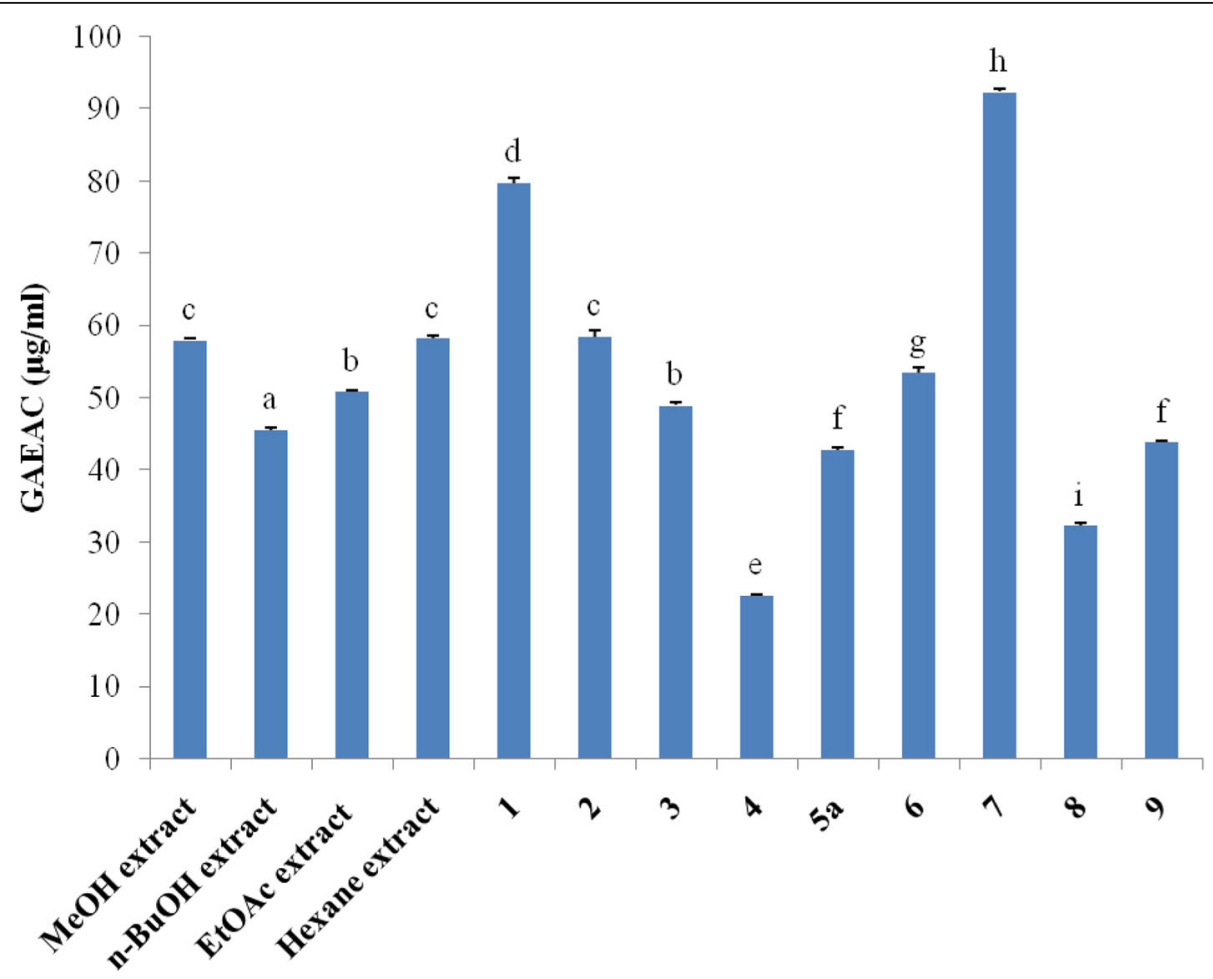

Fig. 2 Gallic acid equivalent antioxidant capacity (GEAC; $\mu \mathrm{g} / \mathrm{ml}$ ) of tested samples. Bars represent the mean \pm SD of three independent experiments carried out in triplicate. Letters a-i indicate significant differences between samples according to one way ANOVA and Waller Duncan test; $p<0.05$. 1: canthiumoside 1; 2: canthiumoside 2; 3: canthiumoside 3; 4: canthiumoside 4; 5a: canthiumoside 5a; 6: shanzhigenin methyl ester; 7: linearin; 7': 1-epilinearin; 8: mussaenoside; 9: shanzhiside methyl ester 


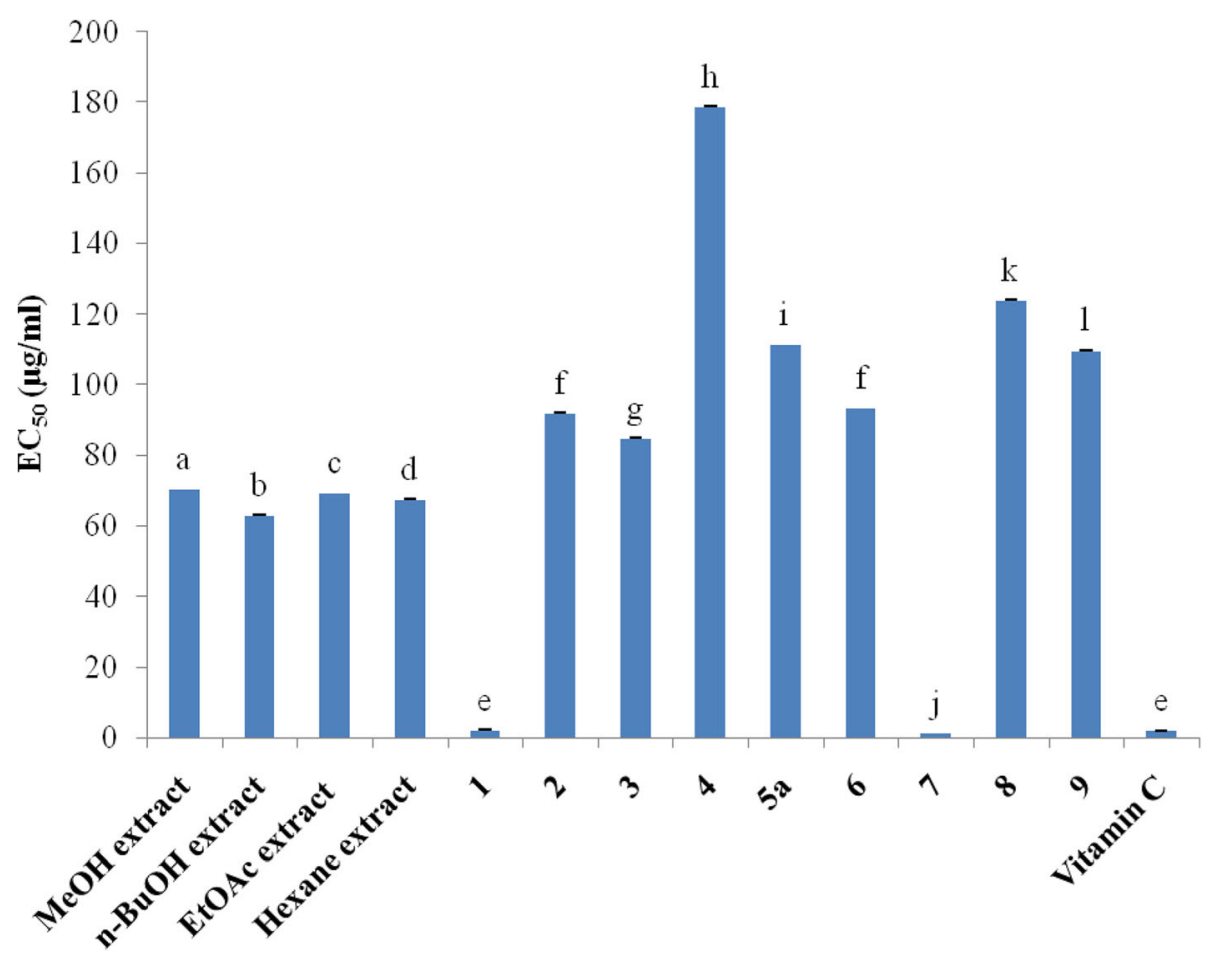

Fig. 3 Equivalent concentrations of test samples scavenging 50\% of DPPH radical $\left(\mathrm{EC}_{50}\right)$. Bars represent the mean \pm SD of three independent experiments carried out in triplicate. Letters a-l indicate significant differences between samples according to one way ANOVA and Waller Duncan test; $p<0.05$. 1: canthiumoside 1; 2: canthiumoside 2; 3: canthiumoside 3; 4: canthiumoside 4; 5a: canthiumoside 5; 6: shanzhigenin methyl ester; 7: linearin; 7': 1-epilinearin; 8: mussaenoside; 9: shanzhiside methyl ester

whereas compound $4\left(\mathrm{EC}_{50}=178.57 \mu \mathrm{g} / \mathrm{ml} ; \mathrm{GAEAC}=\right.$ $22.63 \mu \mathrm{g} / \mathrm{ml})$ displayed the lowest antioxidant activity in both assays $(p<0.05)$; suggesting that the ability of these samples to scavenge DPPH could also reflect their ability to inhibit the formation of ABTS+. Apart from compounds 1 and 7 , the $\mathrm{EC}_{50}$ value of vitamin $\mathrm{C}$ is lower than those of the other tested samples, showing that these samples are less active compared with vitamin C. However, the $\mathrm{EC}_{50}$ value of compound $7\left(\mathrm{EC}_{50}=1.12 \mu \mathrm{g} / \mathrm{ml}\right)$ is lower than that of standard vitamin $C\left(E_{50}=1.74 \mu \mathrm{g} / \mathrm{ml}\right)$, clearly indicating that this compound is more potent than vitamin $\mathrm{C}$ in scavenging free radicals in vitro (Fig. 3). Moreover, the $\mathrm{EC}_{50}$ value of compound 1 $\left(\mathrm{EC}_{50}=2.03 \mu \mathrm{g} / \mathrm{ml}\right)$ is comparable to that of vitamin $\mathrm{C}$ $\left(\mathrm{EC}_{50}=1.74 \mu \mathrm{g} / \mathrm{ml}\right)$. In all, the DPPH and ABTS scavenging activities in this study indicated that compounds $\mathbf{1}$ and 7 belonging to iridoids were potent antioxidants. Previous studies reported the antioxidant activities of some iridoids from plant origin [35-37]. Hence, the antioxidant activity of extracts in this study may be due to the presence of iridoids and phenolic compounds that are capable of donating hydrogen to a free radical in order to remove odd electron, which is responsible for the radical's reactivity $[28,38]$.

\section{Hemolytic activity}

In this study, none of the tested samples showed hemolytic activities against human red blood cells at concentrations up to $512 \mu \mathrm{g} / \mathrm{ml}$ for the extracts and $256 \mu \mathrm{g} / \mathrm{ml}$ for pure compounds (results not shown) indicating that it is non-toxic to normal cells.

\section{Conclusion}

Our results demonstrated that compounds $\mathbf{1}$ and $\mathbf{7}$ under investigation were potent antibacterials and DPPH/ABTS ${ }^{*+}$ radical scavengers.

\footnotetext{
Abbreviations

${ }^{13} \mathrm{C}$-NMR: Thirteen carbon nuclear magnetic resonance; ${ }^{1} \mathrm{H}$ NMR: Proton nuclear magnetic resonance; ABTS: 2,2'-azinobis(3-ethylbenzothiazoline-6sulfonic acid); ATCC: American type culture collection; COSY: Correlation spectroscopy; DMSO: Dimethylsulfoxide; DPPH: 1,1-diphenyl-2-picrylhydrazyl radical; $\mathrm{EC}_{50}$ : Concentration scavenging 50\% DPPH radicals; EtOAc: Ethyl acetate; GAEAC: Gallic acid equivalent antioxidant capacity; HMBC: Heteronuclear multiple bond connectivities; HR-TOFESIMS: High-resolution time of flight electrospray ionization mass spectrometry; HSQC: The heteronuclear single quantum coherence; IP: Institut pasteur; IR: Infra-red; MBC: Minimum bactericidal concentration; MeOH: Methanol; MHA: Mueller Hinton agar; MHB: Mueller Hinton broth; MIC: Minimum inhibitory concentration; NA: Nutrient agar; $\mathrm{n}$ BuOH: n-Butanol; NMR: Nuclear magnetic resonance; NOESY: Nuclear overhauser effect spectroscopy; SRF/CAM: Section de réserve forestière du Cameroun
} 


\section{Acknowledgements}

The authors gratefully acknowledge financial support from the research grant committees of both the University of Dschang and the Cameroonian Ministry of Higher Education.

\section{Funding}

The study was funded by the participating institutions and partly supported by the Cameroonian Ministry of Higher Education.

\section{Availability of data and materials}

The datasets supporting the conclusions of this article are presented in this paper.

\section{Authors' contributions}

CJ contributed to the data collection and analysis. JDT designated the study, did the biological assays and helped in manuscript writing and editing. DN, LVN and JRK supervised and revised the manuscript critically for important intellectual content. All authors read and approved the final manuscript.

\section{Competing interests}

The authors declare that they have no competing interests.

\section{Consent for publication}

No individual clinical data is presented in the article, the information is not relevant.

\section{Ethics approval and consent to participate}

Authorization for the collection of blood was obtained from the Medical and Ethical Committee (in Yaoundé-Cameroon). The written informed consent for participation in the study was obtained from a healthy parent.

\section{Author details}

'Department of Chemistry, Laboratory of Environmental and Applied Chemistry, Faculty of Science, University of Dschang, P.O. Box 67 Dschang, Cameroon. ${ }^{2}$ Department of Biochemistry, Laboratory of Microbiology and Antimicrobial Substances, Faculty of Science, University of Dschang, P.O. Box 67 Dschang, Cameroon. ${ }^{3}$ Groupe Isolement et Structure, Institut de Chimie Moléculaire de Reims (ICMR), CNRS UMR 7312, Bat. 18 BP.1039, 51687, Reims cedex 2, France.

\section{Received: 25 January 2016 Accepted: 13 December 2016} Published online: 05 January 2017

\section{References}

1. Munguti K. Indigenous knowledge in the management of malaria and visceral leishmaniasis among the Tugen of Kenya. IKDM. 1997;5:10-2.

2. Miaron OJ, Kassim O, Ekaya N. Indigenous knowledge: the basis of the Maasai ethnoveterinary diagnostic skills. J Hum Ecol. 2004;16:43-8.

3. Newman DJ, Cragg GM, Snader KM. Natural products as sources of new drugs over the period 1981-2002. J Nat Prod. 2003;66:1022-37.

4. Nair GB, Ramamurthy T, Bhattacharya SK, Mukhopadhyay AK, Garg S, Bhattacharya MK. Spread of Vibrio cholerae 0139 Bengal in India. The Infect Dis. 1994;169:1029-34.

5. Irvine FR. Woody plants of Ghana. London: Oxford University Press; 1961. p. 658.

6. Ampofo O. Plant that heal. Hehminthological Abstract 47. World Health. 1977. p. 247

7. Awah FM, Uzoegwu PN, Ifeonu P, Oyugi JO, Rutherford J, Yao XJ, Fehrmann F, Fowke KR, Eze MO. Free radical scavenging activity, phenolic contents and cytotoxicity of selected Nigerian medicinal plants. Food Chem. 2012;13:1279-86.

8. Achenbach H, Waibel R, Addae-mensah I. Iridoid and other constituents of Canthium subcordatum. Phytochemistry. 1981;20:1591-5.

9. Achenbach H, Waibel R, Addae-mensah I. Shanzhisin methyl ester gentiobioside, a new iridoid-isolation and synthesis. Tetrahedron Lett. 1980;21:3677-8.

10. Joubouhi C, Mabou FD, Tebou FPL, Ngnokam D, Harakat D, Voutquenne NL. Five new iridoïd dimers from the fruits of Canthium subcordatum DC (syn. Psydrax subcordata DC). Phytochemistry Lett. 2015;13:348-54.

11. Achenbach $\mathrm{H}$. Investigations on West African medicinal plants. Pure Appl Chem. 1986;58:653-62

12. Dongo E, Ayafor JF, Sondengam BL, Connoly JD. A new peptide alkaloïd from Canthium arnoldianum. J Nat Prod. 1989;52:840-3.

13. Patro SK, Sasmal D, Mazumndar P, Behera P, Lal UR, Dash SK, Padhy RK. Review on genus Canthium: Special reference to Canthium coromandelicum- an unexplored traditional medicinal plant of Indian Subcontinent. American J Phytomed Clin Therap. 2014:2:796-813.

14. Nyaa TBL, Tapondjou AL, Barboni L, Tamokou JDD, Kuiate JR, Tane P, Park HJ. NMR assignment and antimicrobial/antioxidant activities of $1 \beta$ hydroxyeuscaphic acid from the seeds of Butyrospermum parkii. Nat Prod Sci. 2009;15:76-82

15. Tamokou JDD, Kuiate JR, Tene M, Nwemeguela KTJ, Tane P. The antimicrobial activities of extract and compounds isolated from Brillantaisia lamium. Iranian J Med Sci. 2011;36:24-31.

16. Brand-Williams W, Cuvelier M, Berset C. Use of a free radical method to evaluate antioxidant activity. LWT Food Sci Technol. 1995:28:25-30.

17. Rice-Evans C, Miller NJ. Total antioxidant status in plasma and body fluids. Methods Enzymol. 1994:234:279-93.

18. Mot AC, Pârvu M, Damian G, Irimie FD, Darula Z, Medzihradszky KF, Brem B, Silaghi-Dumitrescu R. A "yellow" laccase with "blue" spectroscopic features, from Sclerotinia sclerotiorum. Process Biochem. 2012;47:968-75.

19. Situ H, Bobek LA. In vitro assessment of antifungal therapeutic potential of salivary histatin-5, two variants of histatin-5, and salivary mucin (MUC7) domain 1. Antimicrob Agents Chemother. 2000;44:1485-93.

20. Kuete V. Potential of Cameroonian plants and derived-products against microbial infections: A review. Planta Med. 2010;76:1-13.

21. Kuete V, Efferth T. Cameroonian medicinal plants: pharmacology and derived natural products. Front Pharmacol. 2010;1:123.

22. Bowersox J. Experimental staph vaccine broadly protective in animal studies. NIH, 1999. Retrieved on 2007-07-28.

23. Jing-Qiu D, Zhong-Li L, Li Y. Non-glycosidiciridoids from Cymbaria mongolica. Phytochemistry. 2002;59:537-42.

24. Sunit S, Kanjana W, Kanyawim K. Iridoid glucosides from the sepals of Barleria lupulina. Planta Med. 2003;69:877-9.

25. Afifi SM, Salama MO, Gohar AA, Marzouk MA. Iridoids with antimicrobial activity from Plumeria alba L. Bull Pharm Sci, Assiut University. 2006;29(1): 215-23.

26. Vidyalakshmi KS, Rajamanickam GV. An iridoid with anticancer activity from the sepals of Mussaenda 'dona aurora'. Indian J Chem. 2009;48:1019-22.

27. Silva AJR, Rezende MC, Pinto CA, Amaral FAC. Cytotoxicity and antibacterial studies of iridoids and phenolic compounds isolated from the latex of Himatanthus sucuuba. African J Biotechnol. 2010:9(43):7357-60.

28. Vertuani S, Beghelli E, Scalambra E, Malisardi G, Copetti S, Dal Toso R, Baldisserotto A, Manfredini S. Activity and stability studies of verbascoside, a novel antioxidant, in dermo-cosmetic and pharmaceutical topical formulations. Molecules. 2011;16:7068-80.

29. Carbonelle B, Denis F, Marmonier A, Pinon G, Vague R. Bactériologie médicale: techniques usuelles. Paris: SIMEP; 1987. p. 228-82.

30. Djouossi MG, Tamokou JDD, Ngnokam D, Kuiate JR, Tapondjou AL, Harakat D, Voutquenne NL. Antimicrobial and antioxidant flavonoids from the leaves of Oncoba spinosa Forssk. (Salicaceae). BMC Compl Altern Med. 2015;15:134

31. Dragland S, Senoo H, Wake K, Holte K, Blomhoff R. Several culinary and medicinal herbs are important sources of dietary antioxidants. J Nutri. 2003; 133:1286-90.

32. Cai Y, Luo Q, Sun M, Corke H. Antioxidant activity and phenolic compounds of 112 traditional Chinese medicinal plants associated with anticancer. Life Sci. 2004;74:2157-84

33. Akinmoladun AC, Obuotor EM, Farombi EO. Evaluation of antioxidant and free radical scavenging capacities of some Nigerian indigenous medicinal plants. J Med Food. 2010;13:444-51.

34. Özen T, Çöllü Z, Korkmaz H. Antioxidant properties of Urtica pilulifera root seed, flower, and leaf extract. J Med Food. 2010;13:1224-31.

35. Ahmad I, Chen S, Peng Y, Chen S, Xu L. Lipoxygenase inhibiting and antioxidant iridoids from Buddleja crispa. J Enzym InhibMed Chem. 2008; 23(1):140-3.

36. Pacifico S, D'Abrosca B, Pascarella MT, Letizia M, Uzzo P, Piscopo V, Fiorentino A. Antioxidant efficacy of iridoid and phenylethanoid glycosides from the medicinal plant Teucrium chamaedris in cell-free systems. Bioorg Med Chem. 2009:17(17):6173-9.

37. Vidyalakshmi KS, Nagarajan S, Vasanthi HR, Venkappaya, Rajamanickam V. Hepatoprotective and antioxidant activity of two iridoids from Mussaenda 'dona aurora'. Z Naturforsch. 2009;64c:329-34.

38. Olayinka AA, Anthony IO. Preliminary phytochemical screening and in vitro antioxidant activities of the aqueous extract of Helichrysum longifolium DC BMC Compl Altern Med. 2010;10:21 